\title{
Liver Toxicity in HIV - Infected Patients Receiving Antiretroviral Therapy That Includes HIV - I Protease Inhibitors.
}

\author{
V.S. Chopra, Mani Goel, Jyoti Batra, Kavita Dhar, Jyotsna Sharma
}

\begin{abstract}
The present paper describes possible connections between antiretroviral therapies (ARTs) - Protease Inhibitor Drugs, used to treat human immunodeficiency virus (HIV) infection and adverse drug reactions (ADRs) encountered predominantly in the liver. Similarly, hepatitis $B$ and lor $C$ virus confection has been associated with a greater risk of Drug - Induced liver Injury, compared with those with no Hepatitis. The study includes prescriptions of 50 HIV seropositive patients (aged between 10 and 50 years) who reported for treatment at the outpatient ward of Santosh Medical College Hospital \& Research Centre, Ghaziabad. Since After initiation to therapy, serum AST and ALT levels increased significantly to $32 \%$ and $18 \%$ and Serum HBs $\mathrm{Ag}$ and HCV levels increased significantly to $36 \%$ and 20\%.The study affirms the potential risk of hepatotoxicity for HIV seropositive patients on an Antiretroviral Protease Inhibitor drugs and calls for continuous monitoring of ARV administration so as to prevent fatal effects of hepatotoxicity.
\end{abstract}

\section{Introduction}

Human immunodeficiency virus (HIV) is the causative agent in AIDS. Infection with HIV is associated with prolonged latent period during which the virus continues to actively replicate, usually resulting in symptomatic illness [1]. The HIV disease progression, which is highly variable in infected individuals, is characterized as rapid, typical or intermediate and late or non- progressors. Since 1981, when the first AIDS cases were reported, more than 33 million people have been diagnosed as infected with HIV [2].

The high HIV/AIDS related morbidity and mortality in developed countries has been dramatically reduced by the advent of effective combination of antiretroviral therapy[3]. Pharmaceutical agents that can be combined to make up highly active antiretroviral therapy (HAART) can be divided into three categories, namely:

- $\quad$ nucleoside reverse transcriptase inhibitors (NRTIs)

- $\quad$ nonnucleoside reverse transcriptase inhibitors (NNRTIs)

- $\quad$ protease inhibitors (PIs), based on their mechanism of action.

Antiretroviral therapies hamper the growth of the HIV virus, thereby causing the suppression of viral particle multiplication and eventually leading to decreased viral load, thereby prolonging the patient's life span.

\begin{tabular}{|c|c|c|}
\hline TYPE OF ARV & CHEMICAL NAME & GENERIC NAME \\
\hline \multirow{6}{*}{$\begin{array}{l}\text { Nucleoside/ } \\
\text { Nucleotide Reverse } \\
\text { Transcriptase } \\
\text { Inhibitors (NRTIs) }\end{array}$} & Зтс & lamivudine \\
\hline & TDF & tenofovir \\
\hline & AZT or ZDV & zidovudine \\
\hline & $A B C$ & abacavir \\
\hline & FTC & emtricitabine \\
\hline & D4T & stavudine \\
\hline \multirow{2}{*}{$\begin{array}{l}\text { Non-nucleoside } \\
\text { Reverse Transcriptase } \\
\text { Inhibitors (NNRTIs) }\end{array}$} & EFV & efavirenz \\
\hline & NVP & nevirapine \\
\hline $\begin{array}{l}\text { Protease Inhibitors } \\
\text { (PI) }\end{array}$ & LPV/r & $\begin{array}{l}\text { lopinavir + } \\
\text { ritonavir }\end{array}$ \\
\hline
\end{tabular}

The pathogenesis of drug-induced liver disease normally involves the participation of the parent drug or its metabolite that either affects the cell biochemistry directly or indirectly by eliciting an immune response. Twenty-one anti-HIV medications have been approved by the U.S. Food and Drug Administration (FDA) for the treatment of HIV, However, in approximately $6 \%$ to $30 \%$ of treated patients, antiretroviral therapy is associated with significant increases in serum liver enzymes, which may require discontinuation of HIV treatment.[4-5] In addition, because of shared routes of transmission, chronic viral hepatitis is common, with an estimated $30 \%$ and $10 \%$ of HIV-infected persons co infected with hepatitis virus (HCV) and hepatitis B virus 
(HBV), respectively.[6-8].Although the specific mechanism by which viral hepatitis increases this risk is not known.

The prescribing information for all ARV approved by the US Food and Drug Administration (FDA) includes the following warning: (1) hepatitis, including cases resulting in hepatic failure and death, has been reported in patients taking PIs; and (2) there may be an increased risk for alanine aminotransferase and/or aspartate aminotransferase (ALT/AST) elevations in patients with preexisting liver disease or underlying hepatitis B virus (HBV) or hepatitis C virus (HCV) infection. So, the impediments to effective use of Highly Active Antiretroviral Therapy (HAART) include the adverse effects associated with the use of these drugs. Liver toxicity or Hepatotoxicity is an important complication of HIV infection and is well described as a component of the broad spectrum of antiretroviral therapy toxicity [9-15].

\section{Hepatotoxicity}

The first sign of damage to the liver is an increase in liver enzyme levels in the blood. When the liver is damaged, its enzymes are released into the bloodstream, where the levels can be measured by blood tests. These are called liver function tests (LFTs). Enzyme levels that are routinely checked as part of LFTs includes: • alanine aminotransferase (ALT) • aspartate aminotransferase (AST) • gamma-glutamyltransferase (GGT)

Consequently, hepatologists are frequently asked to evaluate HIV infected patients with abnormal liver enzymes, and to assess the causal role of antiretroviral drugs and chronic viral hepatitis. 6-30\% of patients treated with antiretrovirals develop significant increases in serum liver enzymes, which may require discontinuation of ART [16].

\section{Methodology}

The present study was a cross sectional analysis of the incidence of significant liver enzyme elevations following the initiation of antiretroviral therapy and to define the role of chronic viral hepatitis in its development, which included all prescriptions of 50 HIV seropositive patients (aged between 10 and 50 years) who reported for treatment at the outpatient ward of Santosh Medical College Hospital \& Research Centre, Ghaziabad .

\section{Inclusion Criteria:}

HIV seropositive patients will be included who will be taking the HAART (Highly active antiretroviral therapy) for at least 3- 4 months .HIV positive volunteers who returned their informed consent forms duly signed will be recruited irrespective of their gender or clinical state of the disease.

\section{Exclusion Criteria:}

Alcoholic patients, congestive heart failure, liver tumors \& patients with bone disorders will be excluded. Medication prescriptions were recorded by name, dose and number dispensed in the patient chart. The information was compiled and analyzed in consultation with the concerned consultant. Data of patients matching inclusion criteria was recorded only. Data like age, diagnosis, ongoing treatment was recorded from case record of patients. Identity of patient was to be kept confidential. Hepatoxicity was examined for all PInaïve patients receiving an initial PI containing antiretroviral regimens, According to practise guideline, all patients had laboratory testing prior to therapy and typically 4weeks after initiation of therapy.

\section{Data to be analyzed as under:}

- Age wise distribution

- Gender wise distribution

- Percentage of Protease Inhibitors Prescribed in HIV patients.

- Percentage of Concomitant prescribed

Parameters to be compared in HIV infected patients before initiation of Antiretroviral therapy with the patients after receiving Antiretroviral therapy with or without hepatis B or C Infection.

- To compare serum SGOT (AST),

- To compare serum SGPT (ALT),

Other Parameters:

- HBs Ag positive

- HCV antibody positive

\section{Results}


Liver Toxicity in HIV - Infected Patients Receiving Antiretroviral Therapy That Includes HIV ....

Table: 1 Age wise distribution and Gender wise distribution

\begin{tabular}{|l|l|l|l|}
\hline Age & Male & Female & Total(\%) \\
\hline $\mathbf{1 0 - 2 0}$ & - & 1 & $2 \%$ \\
\hline $\mathbf{2 0 - 3 0}$ & 13 & 2 & $30 \%$ \\
\hline $\mathbf{3 0 - 4 0}$ & 21 & - & $42 \%$ \\
\hline $\mathbf{4 0 - 5 0}$ & 13 & - & $26 \%$ \\
\hline Total & 47 & 3 & $100 \%$ \\
\hline
\end{tabular}

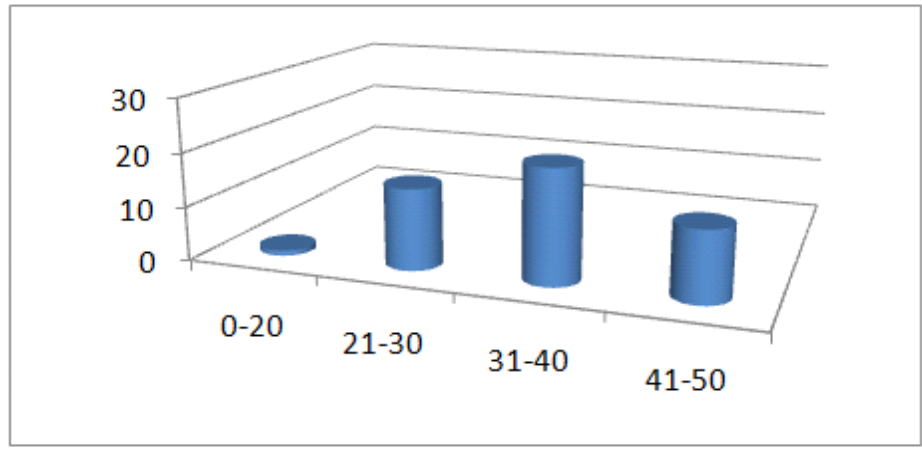

Fig 1: Age wise distribution

Fig 2: Gender wise Distribution.

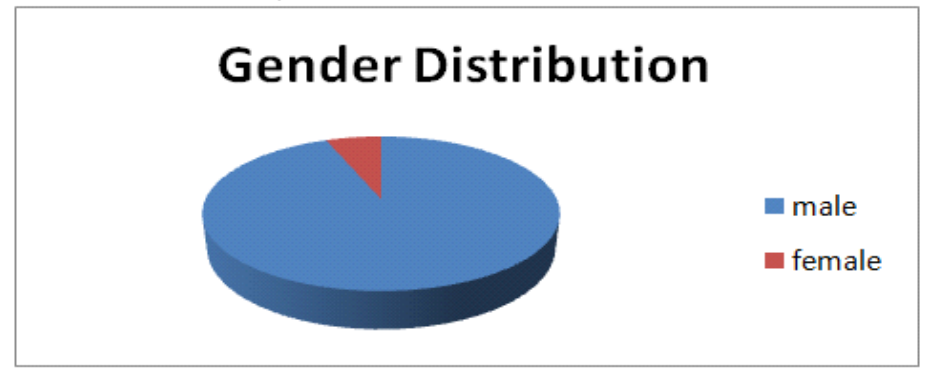

Table 2: Antiretroviral Drugs Prescribed in HIV patients.

\begin{tabular}{|c|c|c|}
\hline Antiretrovirals & No. of patients & Percentage $(\%)$ \\
\hline \multicolumn{3}{|l|}{ PI's exposure } \\
\hline - Nelfinavir & 22 & $44 \%$ \\
\hline - Lopinavir/ Ritonavir & 5 & $10 \%$ \\
\hline - Indinavir & 7 & $14 \%$ \\
\hline - Indinavir/ Ritonavir & 6 & $12 \%$ \\
\hline - $\quad$ Saquinavir/ Ritonavir & 10 & $20 \%$ \\
\hline \multicolumn{3}{|l|}{ NRTI exposure } \\
\hline - Zidovudine & & \\
\hline - Lamivudine & 10 & $20 \%$ \\
\hline - $\quad$ Tenofovir & 40 & $80 \%$ \\
\hline & 1 & $2 \%$ \\
\hline \multicolumn{3}{|l|}{ NNRTI exposure } \\
\hline - $\quad$ Efavirenz & 9 & $18 \%$ \\
\hline - Nevirapine & 12 & $24 \%$ \\
\hline
\end{tabular}

Table 3:

\begin{tabular}{|l|l|l|l|l|l|}
\hline & \multicolumn{6}{|l|}{ Before Initiation of therapy } & \multicolumn{2}{l|}{ After Initiation of Therapy } & \multirow{2}{*}{$\begin{array}{l}\text { Total } \\
\text { Raised(50) }\end{array}$} \\
\hline & Normal & Raised & Normal & Raised & \\
\hline AST & 45 & 5 & 29 & 16 & $32 \%$ \\
\hline ALT & 47 & 3 & 43 & 9 & $18 \%$ \\
\hline
\end{tabular}

Table 4:

\begin{tabular}{|l|l|l|l|l|l|}
\hline & \multicolumn{2}{|l|}{ Before Initiation of therapy } & After Initiation of Therapy & \multirow{2}{*}{ Total Positive (50) } \\
& Positive & Negative & Positive & Negative & \\
\hline HBs Ag & 6 & 44 & 18 & 32 & $36 \%$ \\
\hline HCV antibody & 3 & 47 & 10 & 40 & $20 \%$ \\
\hline
\end{tabular}


Between January 2014 and December 2014, 50 patients were prescribed their first PI- containing antiretroviral regimen (Nelfinavir 22 patients ,Lopinavir/ Ritonavir 5 patients, Indinavir 7 patients, Indinavir/ Ritonavir 6 patients and Saquinavir/ Ritonavir 10 patients) met inclusion criteria. Significant differences were detected between groups with respect to Age, Gender, HBsAg and, HCV staus and pretreatment ALT and AST levels Prior to initiation of therapy, the AST and ALT levels were raised in $10 \%$ and $6 \%$ of patients, during follow up, serum AST and ALT levels increased significantly to 32\% and 18\%. Similarly Prior to initiation of therapy, $\mathrm{HBs} \mathrm{Ag}$ and, $\mathrm{HCV}$ were raised in $12 \%$ and $6 \%$ of patients, during follow up, Serum $\mathrm{HBs} \mathrm{Ag}$ and $\mathrm{HCV}$ levels increased significantly to $36 \%$ and $20 \%$.

\section{Discussion}

Protease inhibitors (PIs) have become one of the integral parts of the standard treatment of HIV infection as outlined in multiple national and international guidelines for the management of persons infected with HIV. [17,18]. Hepatic injury attributed specifically to PI regimens alone are difficult to assess because of the presence of many complicating factors, such as drug-drug interactions, the clinical condition of the patient, and the hepatic effects of various comorbid diseases. Nonetheless, across a number of studies, coinfection with chronic HBV and/or HCV has been consistently associated with a greater risk of severe liver injury compared with patients who have concurrent liver disease. $[2,3,13,19]$

However, recent data and Several studies have found that HCV-and/or HBV-coinfected patients are at increased risk to develop severe hepatotoxicity following initiation of antiretroviral therapy containing HIV-1 protease inhibitors (PIs), are associated with hepatotoxicity.The study conducted in Baltimore, Maryland determine the incidence of severe hepatotoxicty during PI therapy among 212 patients, the incidence of severe hepatotoxicity was $10.4 \%$ (95\% CI, 7.2\%-14.4\%).,HCV Antibody was present in $48 \%$ of the patients, and hepatitis B surface antigen (HBsAg) was present in 3.3\%. [1]

In a similar study that involved patients observed at a single university clinic in the Swiss ,followed- up 394 patients after the initiation of HAART, Overall, 70 (18\%) patients developed significant Liver Enzyme Elevation.Of the 29 patients who were HBsAg positive, 13 (45\%) had LEEs, and, of the 57 patients who were anti-HCV positive, 19(33\%) developed LEEs. [2] Drug interactions should be examined closely whenever prescribing medication in combination with PIs, this is a particularly important consideration with ritonavir, given its powerful inhibition of cytochrome p450 (CYP) 3A4 and its effects on several other mechanisms of drug interactions. Among the PI's, in some studies full dose ritonavir (RTV) has been found to be more hepatotoxic [20].although these results have not been confirmed by others $[\mathbf{1 3 , 2 1}$ ] Thus, close monitoring of HIV infected patients is essential in reducing the morbidity and mortality of HIV patients. Monitoring HIV disease progression requires, Knowledge about indications for antiretroviral therapy(ART) use in chronically human immunodeficiency virus (HIV-) infected patients, relative efficacy of different regimens and laboratory monitoring.

\section{References}

[1]. Sulkowski MS, Thomas DL, Chaisson RE, Moore RD. Hepatotoxicity associated with antiretroviral therapy in adults infected with HEPATOLOGY, Vol. 35, No. 1, 2002 SULKOWSKI ET AL. 187 human immunodeficiency virus and the role of hepatitis C or B virus infection. JAMA 2000;283:74-80.

[2]. Den Brinker M, Wit FW, Wertheim-van Dillen PM, Jurriaans S, Weel J, van Leeuwen R, Pakker NG, et al. Hepatitis B and C virus co-infection and the risk for hepatotoxicity of highly active antiretroviral therapy in HIV-1 infection. AIDS 2000;14:2895-2902.

[3]. Nunez M, Lana R, Mendoza JL, Martin-Carbonero L, Soriano V. Risk factors for severe hepatic injury after introduction of highly active antiretroviral therapy. J Acquir Immune Defic Syndr 2001;27: 426-431.

[4]. Martinez E, Blanco JL, Arnaiz JA, Perez-Cuevas JB, Mocroft A, Cruceta A, Marcos MA, et al. Hepatotoxicity in HIV-1-infected patients receiving nevirapine-containing antiretroviral therapy. AIDS2001;15:1261-1268.

[5]. Saves M, Vandentorren S, Daucourt V, Marimoutou C, Dupon M, Couzigou P, Bernard N, et al. Severe hepatic cytolysis: incidence and risk factors in patients treated by antiretroviral combinations. Aquitaine Cohort, France, 1996-1998. Groupe dEpidemiologie Clinique de Sida en Aquitaine (GECSA). AIDS 1999;13:F115-F121.

[6]. Zylberberg H, Pol S. Reciprocal interactions between human immunodeficiency virus and hepatitis $\mathrm{C}$ virus infections. Clin Infect Dis 1996;23:1117-1125.

[7]. Sulkowski MS, Mast EE, Seeff LB, Thomas DL. Hepatitis C virus infection as an opportunistic disease in persons infected with human immunodeficiency virus. Clin Infect Dis 2000;30(Suppl 1):S77-S84.

[8]. Perrillo RP, Regenstein FG, Roodman ST. Chronic hepatitis B in asymptomatic homosexual men with antibody to the human immunodeficiency virus. Ann Intern Med 1986;105:382-383.

[9]. Rodriguez-Rosado R, Garcia-Samaniego J, Soriano V. Hepatotoxicity after introduction of highly active antiretroviral therapy. AIDS 1998, 12:1256.

[10]. Save`s M, Vandentorren S, Daucourt V, Marimoutou C, Dupon M, Couzigou P, et al. Severe hepatic cytolysis: incidence and risk factors in patients treated by antiretroviral combinations. Aquitaine Cohort, France, 1996-1998. AIDS 1999, 13:F115-F121.

[11]. Gisolf EH, Dreezen C, Danner SA, for the Prometheus Study Group. Risk factors for hepatotoxicity in HIV-1-infected patients receiving ritonavir and saquinavir with or without stavudine. Clin Infect Dis 2000, 31:1234-1239.

[12]. Monforte Ade A, Bugarini R, Pezzotti P, for the ICONA (Italian Cohort of Naive for Antiretrovirals) Study Group. Low frequency of severe hepatotoxicity and association with HCV coinfection in HIV-positive patients treated with HAART. J AIDS 2001, $28: 114-123$ 
[13]. Aceti A, Pasquazzi C, Zechini B, for the LIVERHAART Group. Hepatotoxicity development during antiretroviral therapy containing protease inhibitors in patients with HIV: the role of hepatitis B and C virus infection. J AIDS 2002, 29:41-48.

[14]. Sulkowski MS, Thomas DL, Mehta SH, Chaisson RE, Moore RD. Hepatotoxicity associated with nevirapine- or efavirenzcontaining antiretroviral therapy: role of hepatitis C and B infections. Hepatology 2002, 35:182-189.

[15]. Wit FW, Weverling GJ, Weel J, Jurriaans S, Lange JM. Incidence of and risk factors for severe hepatotoxicity associated with antiretroviral combination therapy. J Infect Dis 2002, 186:23-31.

[16]. Palella FJ, Jr., Delaney KM, Moorman AC, Loveless MO, Fuhrer J, Satten GA, et al. Declining morbidity and mortality among patients with advanced human immunodeficiency virus infection. HIV Outpatient Study Investigators. N Engl J Med 1998; 338:853-860.

[17]. Yeni PG, Hammer SM, Carpenter CC, et al. Antiretroviral treatment for adult HIV infection in 2002: updated recommendations of the International AIDS Society-USA Panel. JAMA 2002; 288:222-35.

[18]. Department of Health and Human Services, Henry J. Kaiser Family Foundation. Guidelines for the use of antiretroviral agents in HIVinfected adults and adolescents. Available at: http://www.hivatis.org. Accessed 4 February, 2002.

[19]. Gisolf EH, Dreezen C, Danner SA, Weel JL, Weverling GJ. Risk factors for hepatotoxicity in HIV-1-infected patients receiving ritonavir and saquinavir with or without stavudine. Prometheus Study Group. Clin Infect Dis 2000; 31:1234-9.

[20]. Bofanti P, Landonia S., Ricci E., Artinelli C., Fortuna P., Faggion I., Quirino T. Risk factors for Hepatotoxicityin patients treated with highly active Antiretroviral therapy. J Acquir Immune Defic Syndr. 2001;27:316-318.

[21]. Cooper C., Parbhakar M., Angel J. Hepatotoxicity associated with antiretroviral therapy containing dual versus single protease inhibitors in individuals co infected with hepatitis C virus and HIV. Clin Infect Dis.2002;34:1259-1263. 